\title{
NILAI PENDIDIKAN DALAM CERITA RAKYAT BAKUMPAI DI KELURAHAN ULU BENTENG KECAMATAN MARABAHAN
}

\author{
Irni Cahyani dan Abdus Salam Muhdi \\ Unit Pengelola Program Studi Pendidikan Bahasa dan Sastra Indonesia \\ STKIP PGRI Banjarmasin \\ Jalan Sultan Adam Komplek H. Iyus, No. 18 RT. 23 Banjarmasin, \\ Kalimantan Selatan, Kode pos 70121 \\ email: irnicahyani08091987@gmail, abdus.salammuhdi@gmail.com.
}

\begin{abstract}
ABSTRAK
Latar belakang dalam penelitian ini mengkaji mengenai nilai-nilai yang terkandung dalam cerita rakyat Bakumpai, yang berjudul Si Supak dan Si Gantang dan cerita rakyat Mang Raja Haji dan Tujuh Putri. Tujuan penelitian ini adalah: (1) Mengetahui nilai pendidikan yang berhubungan dengan nilai sosial dalam cerita rakyat Bakumpai, (2) Mengetahui nilai pendidikan yang berhubungan dengan moral dalam cerita rakyat Bakumpai.

Penelitian ini menggunakan pendekatan sosiologi sastra, metode yang digunakan dalam penelitian ini ialah metode deskriptif analisis. Subjek dalam penelitian ini yaitu dua orang penutur cerita rakyat Bakumpai merupakan sesepuh yang tinggal dilokasi penelitian. Lokasi dalam penelitian ini dilakukan di Kelurahan Ulu Benteng, Jalan Panglima Batur RT.06 RW.001, Kecamatan Marabahan Kabupaten Barito Kuala. Sumber data dalam penelitian ini adalah dokumen cerita rakyat Bakumpai yang telah diceritakan oleh pencerita (informan). Dalam mengumpulkan data tersebut digunakan teknik dokumentasi dan observasi teks. Sedangkan dalam menganalisis data menggunakan teknik deskriptif interpretatif, yaitu peneliti memaparkan data secara keseluruhan terlebih dahulu. Setelah data terkumpul peneliti menginterpretasikannya.

Hasilnya dapat dikemukakan sebagai berikut: 1. Nilai pendidikan sosial yang terdapat yaitu: a) Tolong-menolong, dalam cerita tersebut yaitu sama-sama memiliki perilaku tolong-menolong, b) Keteguhan hati dengan keyakinan dan keteguhan hati terus berharap agar ayah mereka dapat sembuh kembali, c) Setia kawan, dalam keadaan apapun mereka selalu membaginya satu sama lain, d) Perjuangan hidup, dari masing-masing tokoh disampaikan secara tersurat, e) Peduli sesama, dalam cerita tersebut yaitu sama-sama memiliki sikap peduli sesama. 2. Nilai pendidikan moral yang terdapat yaitu: a) Pantang menyerah, dalam cerita itu sama-sama memiliki sifat pantang menyerah yang tertanam dalam diri mereka masing-masing, b) Semangat, dalam kedua cerita tersebut yaitu mereka memiliki semangat yang tinggi dan c) Tanggung jawab yang tinggi ditunjukkan oleh sosok ibu dan ayah dalam kedua cerita rakyat Bakumpai.
\end{abstract}

Kata-kata kunci: nilai pendidikan, cerita rakyat

\section{PENDAHULUAN}

Sebuah karya sastra merupakan budi pekerti manusia terhadap lingkungan alamiah dan juga lingkungan alam semesta. Karya sastra juga merupakan media bagi pengarang untuk menuangkan pengalaman jiwa, begitu juga dengan karya sastra lisan termasuk Cerita Rakyat Bakumpai di Kelurahan Ulu Benteng Kecamatan Marabahan. Dahulu kala, menurut sejarah orang belum kenal 
tulis menulis, sehingga cerita-cerita hanya disampaikan lewat tutur kata. Cerita-cerita itu biasanya disebut dengan dongeng kerajaan, dan banyak lagi macamnya. Dongeng atau cerita tersebut diceritakan secara turun-temurun.Demikian juga daerah di Kalimantan, khususnya Kalimantan Selatan masyarakat Bakumpai,khususnya suku Dayak juga mempunyai cerita rakyat tersebut. Cerita itu berjudul "Si Gantang dan Si Supakjuga cerita Mang Raja Haji dan Tujuh Putri."Cerita rakyat inipun dahulu hanya diceritakan secara tutur kata. Walau demikian, masyarakat di daerah itu begitu percaya dengan cerita tersebut, bahkan masyarakat di daerah Dayak Bakumpai menjadikan cerita itu sebagai pedoman dalam menjalankan suatu adat-istiadat.

Dari rasa keingintahuan yang kuat untuk menganalisis nilai pendidikan dari cerita rakyat Bakumpai itulah, maka peneliti merasa tertarik untuk mengadakan penelitian tentang cerita rakyat. Cerita rakyat yang menjadi pilihan peneliti adalah cerita rakyat dari daerah Kalimantan Selatan, khususnya dari suku Dayak Bakumpai. Peneliti ingin mendapatkan nilai-nilai pendidikan yang terkandung dalam cerita rakyat tersebut lewat tokoh yang ada di dalamnya. Oleh karena itu, penelitian ini berjudul: Nilai Pendidikan dalam Cerita Rakyat Bakumpai di Kelurahan Ulu Benteng Kecamatan Marabahan.

Pemilihan cerita rakyat Bakumpai sebagai objek penelitian adalah karena cerita ini sangat terkenal di Marabahan, khususnya di kalangan suku Bakumpai Marabahan yang merupakan daerah tempat tinggal peneliti. Selain itu, dalam cerita rakyat Bakumpai juga banyak mengandung nilainilai pendidikan yang sangat erat melekat dengan manusia sebagai rakyat. Cerita rakyat tidak hanya berfungsi untuk mendidik, tetapi juga menghibur.Melalui hiburan dari cerita yang ada, penutur menanamkan nilai-nilai pendidikan kepada para pendengar, baik anak-anak ataupun orang dewasa. Dengan ditanamkan nilai pendidikan kepada anak, diharapkan anak tumbuh menjadi pribadi dewasa yang sempurna. Dengan membaca cerita rakyat Bakumpai yang telah didengar dan dicatat oleh peneliti, diharapkan para pembaca dapat memahami nilai-nilai pendidikan yang terdapat dalam cerita rakyat Bakumpai Si Gantang dan Si Supakjuga cerita Mang Raja Haji dan Tujuh Putriyang disajikan.

Cerita rakyat Bakumpai Si Gantang dan Si Supak juga cerita Mang Raja Haji dan Tujuh Putri memiliki tema yang tidak jauh dari keseharian masyarakat Bakumpai dan menampilkan konflik-konflik yang sering dijumpai dalam kehidupan. Di akhir cerita rakyat tersebut, diharapkan para pembaca merasa puas, senang dan mampu memperoleh atau mengambil hikmah berupa nilainilai pendidikan dari cerita rakyat tersebut, kemudian menerapkannya dalam kehidupan nyata. 
Cerita rakyat adalah kisahan yang aslinya beredar secara lisan dan kepercayaan masyarakat, seperti mite. Zaidan, dkk (2007:51). Cerita rakyat adalah bagian dari karya sastra yang cara penyampaiannya disampaikan secara lisan. Cerita rakyat biasanya diwariskan atau diceritakan secara turun temurun. Cerita rakyat juga disebut sebagai sastra lisan. Menurut Djamaris dalam Setya (1990:2), mendefinisikan mengenai cerita rakyat itu biasanya disampaikan secara lisan oleh orang yang hafal ceritanya. Itulah sebabnya cerita rakyat itu disebut sastra lisan (oral literature). Cerita disampaikan seorang tukang cerita sambil duduk-duduk di suatu tempat, kepada siapa saja, baik anak-anak maupun orang dewasa.

\section{METODE}

Pendekatan yang digunakan dalam penelitian ini yaitu pendekatan sosiologi sastra yang mengkaji masalah nilai-nilai pendidikan pada tokoh dalam cerita rakyat Bakumpai. Menurut Endraswara dalam Akbar, dkk, (2013:55), menyatakan bahwa sosiologi sastra adalah cabang penelitian sastra yang bersifat reflektif. Penelitian ini banyak diminati oleh peneliti yang ingin melihat sastra sebagai cermin kehidupan masyarakat. Arenanya, asumsi dasar penelitian sosiologi sastra adalah kelahiran sastra tidak dalam kekosongan sosial. Metode dalam penelitian karya sastra sangat diperlukan, karena merupakan suatu jalan atau cara kerja untuk memahami suatu objek yang menjadi sasaran penelitian. Metode penelitian yang digunakan dalam menganalisis cerita rakyat Bakumpai adalah metode deskriptif analisis. Dalam penelitian ini, peneliti membuat penggambaran (deskripsi) mengenai nilai sosial dan nilai moral. Sumber data yang digunakan dalam penelitian ini adalah dokumen. Dokumen yang digunakan adalah cerita rakyat Bakumpai yang telah diceritakan oleh pencerita (informan), dimana cerita tersebut telah dicatat dan dibuat menjadi sebuah cerita rakyat Bakumpai. Teknik pengumpulan data yang digunakan adalah teknik dokumentasi dan observasi teks, yaitu dengan cara mengumpulkan bahan acuan yang relevan untuk dijadikan sumber dalam membahas nilai-nilai pendidikan dalam cerita rakyat Bakumpai. Langkah-langkah kerja pengumpulan data dan penelitian ini yaitu: Mencatat cerita yang diceritakan oleh informan, mengklasifikasikan data, memilih data dan menentukan data sesuai dengan masalah yang dirumuskan, mendeskripsikan data yang telah ditentukan.

Setelah data terkumpul, kegiatan selanjutnya adalah melakukan analisis data, bertolak dari metode yang digunakan dalam penelitian, maka teknik yang digunakan dalam analisis data adalah teknik deskriptif interpretatif, yaitu peneliti memaparkan data secara keseluruhan terlebih dahulu. Setelah data terkumpul peneliti menginterpretasikannya. Untuk menganalisis data yang dilakukan 
melalui tahap-tahap sebagai berikut: Tahap membaca cerita rakyat yang telah dicatat dan memahami cerita untuk menemukan nilai pendidikan yang terdapat dalam cerita rakyat tersebut, maka cerita itu harus dibaca secara keseluruhan. Hasil pemahaman cerita tersebut digunakan untuk menganalisis nilai pendidikan yang terdapat dalam cerita rakyat tersebut. Tahap menandai dan mengklasifikasikan data sesuai dengan perumusan masalah. Tahap analisis data, peneliti mulai memberikan makna terhadap data yang telah didapat.

\section{HASIL DAN PEMBAHASAAN}

\section{Nilai Pendidikan Sosial dalam Cerita Rakyat Bakumpai \\ Tolong-menolong}

Tolong-menolong atau bantu-membantu merupakan hal yang tidak bisa ditinggalkan dalam kehidupan di masyarakat. Untuk mewujudkan kehidupan yang harmonis dan saling lengkapmelengkapi sesama manusia, maka manusia saling memerlukan satu sama lain. Jadi antara konsep penting yang perlu ada dalam hubungan sesama manusia ialah tolong-menolong.

Tolong-menolong dapat dilihat pada kutipan berikut ini:

"Untuk mengobati Ayahnya suatu hari si Gantang dan si Supak pergi ke hutan yang tidak jauh dari tepi pantai untuk mencari dedaunan. Yang dipetik mereka adalah segala daun yang tumbuh di ladang dan di tepi pantai...."

Kutipan di atas, menerangkan bahwa untuk mengobati ayahnya yang sedang sakit, maka si Gantang dan si Supak pergi ke hutan untuk mencari dedaunan dengan tujuan dedaunan tersebut dijadikan ramuan obat. Mereka berharap meskipun dedaunan yang mereka dapat itu tidaklah terlalu membantu, namun mereka tetap terus berusaha agar ayah mereka dapat tertolong meskipun dengan obat dari dedaunan yang sederhana. Dengan dedaunan tersebut Si Gantang dan Si Supak berharap dapat dijadikan obat ramuan yang dapat menolong ayahnya yang sedang sakit di rumah agar dapat sehat kembali.

Dalam kutipan lainnya yaitu:

"Sesampainya di rumah, dedaunan itu diperlihatkan kepada Ibunya. Ibunya bertanya, "Untuk apakah dedaunan itu dibawa ke rumah". Si Supak menjawab, "Untuk mengobati Ayah yang sedang sakit."

Kutipan di atas menerangkan setelah mereka berhasil mencari dedaunan, maka si Gantang dan si Supak segera pulang ke rumah. Setibanya di rumah mereka memperlihatkan dedaunan tersebut kepada ibunya. Ibu bertanya kepada mereka, "untuk apa daun itu", "untuk obat Ayah" jawab si Supak. Dengan dedaunan tersebut Si Gantang dan Si Supak berharap dapat dijadikan 
ramuan obat, sehingga dapat menolong ayahnya yang sedang sakit dirumah agar dapat sehat kembali.

Tolong-menolong dapat dilihat pada kutipan berikut ini:

Semalaman Mang Raja Haji tidak dapat tidur karena menahan rasa sakit yang bukan kepalang, ia terus menutup hidungnya dengan kain. Sering kali ia menggerang kesakitan dan minta ampun. Si Bungsu kemudian mengambil jahe dan kunyit untuk ditumbuk halus. Setelah selesai ditumbuk, lalu ia bawa masuk ke dalam kamar. "Ayah bukalah wajahmu, aku akan mengobati Ayah," kata si Bungsu...

Kutipan di atas menerangkan bahwa Ayah tidak dapat tidur, karena sakit yang dideritanya, bahkan sesekali terdengar suaranya mengerang kesakitan dan minta ampun. Sementara itu, si Bungsu menghaluskan jahe dan kunyit, ia bermaksud ingin mengobati Ayahnya. Si Bungsu berusaha untuk menolong ayahnya yang merasakan sakit, dengan cara memberikan obat berupa jahe dan kunyit yang telah ditumbuk halus.

\section{Keteguhan Hati}

Keteguhan hati berkaitan juga dengan niat, keyakinan, yakin dengan apa yang akan dilakukannya dan tidak ragu sedikitpun dalam melakukan sesuatu. Keteguhan hati adalah syarat utama agar seseorang memiliki kedewasaan emosional dan menjadi syarat dalam menggapai keberhasilan, karena dimulai dari keyakinan kita menjadi optimis untuk dapat berhasil dalam mengerjakan sesuatu.

Keteguhan hati dapat dilihat pada kutipan berikut:

"Dari hari kehari penyakit yang diderita Ayah mereka semakin parah, segala macam obat sudah dimakankan, semua tabib sudah dipanggil, tetapi penyakit ayah si Supak dan si Gantang tidak sembuh juga."

Kutipan di atas menerangkan Ayah sedang sakit parah, untuk menyembuhkan ayah mereka yang sedang sakit, segala macam usaha sudah dicoba termasuk memanggil para tabib. Si Gantang dan Si Supak terus berharap agar ayahnya dapat sembuh dari sakitnya, dan dengan keyakinan hati, serta niat yang sungguh-sungguh, Si Gantang dan Si Supak mencari segala cara untuk mengobati ayahnya, hingga Si Gantang dan Si Supak mencoba untuk memanggil Tabib dengan harapan dapat membuat ayahnya sehat kembali.

Keteguhan hati dapat dilihat pada kutipan berikut:

“Apakah sudah ditemukan obatnya, Bang Yujang ?" tanya si Bungsu yang dari tadi menunggu. 
"Tenang, obat itu sudah aku temukan dan mudah-mudahan obat itu bisa menyembuhkan Ayahmu". Kata Yujang Helo.

Kutipan di atas menjelaskan bahwa si Bungsu menanyakan kepada Yujang Helo, apakah dia sudah menemukan obat untuk Ayahnya. Yujang Helo menjawab ya, mudah-mudahan obat yang dibawanya bisa menyembuhkan Ayah si Bungsu.

\section{Setia Kawan}

Setia kawan merupakan perilaku yang selalu setia di saat susah maupun senang. Orang yang selalu dapat dipercaya. Bentuk setia kawan dapat diwujudkan dengan rela berkorban untuk teman atau sahabat tanpa mengharapkan imbalan.

Setia kawan dapat kita lihat pada kutipan berikut:

"Si Gantang dan Si Supak adalah dua bersaudara, kemanapun pergi mereka selalu berdua, sifatnya yang lucu kadang membuat semua orang tertawa dibuatnya terutama Ayah dan Ibunya."

Kutipan di atas menerangkan bahwa Si Gantang dan Si Supak adalah dua bersaudara, mereka selalu berdua kemanapun mereka pergi, mereka juga lucu, semua orang selalu tertawa melihat tingkah lakunya, terutama Ayah dan Ibu mereka. Sifat mereka yang seperti itu, dengan pergi kemanapun bersama-sama, menumbuhkan sikap setia kawan. Dimana Si Gantang dan Si Supak mengharapkan agar dapat merasakan suka dan duka bersama-sama, dan dapat berbagi kebahagiaan kepada orang-orang yang ada disekitarnya, terutama ayah dan ibu Si Gantang dan Si Supak.

Setia kawan dapat kita lihat pada kutipan berikut:

"Mang Raja Haji kemudian berunding dengan ketujuh putrinya. Awalnya si Bungsu tidak mau menerima karena merasa tidak nyaman dengan kakakkakaknya yang dilangkahinya, tetapi karena rasa sayang dengan Ayahnya dan atas persetujuan kakak-kakaknya dia bersedia menerima persyaratan Yujang Helo. Setelah mendengar keputusan mereka akhirnya Yujang Helo pulang dengan harapan yang besar."

Kutipan di atas menjelaskan bahwa saat itu terjadi perundingan antara Mang Raja Haji dan ketujuh putrinya tentang persyaratan yang diajukan oleh Yujang Helo. Yujang Helo meminta si Bungsu untuk menjadi istrinya, tetapi permintaan itu tidak langsung diterima oleh si Bungsu, karena dia merasa tidak nyaman terhadap kakak-kakaknya. Namun, karena rasa sayang terhadap Ayahnya dan atas persetujuan kakak-kakaknya, akhirnya dia mau menerima persyaratan Yujang Helo. 


\section{Perjuangan Hidup}

Perjuangan hidup merupakan suatu bentuk usaha untuk melakukan apa saja untuk dapat melanjutkan hidup. Selalu bekerja keras dalam memenuhi setiap kebutuhan yang diperlukan.

Perjuangan hidup dapat dilihat pada kutipan berikut:

"Saat perut lapar mereka hanya makan buah-buahan saja, karena waktu itu musim buah. Ada buah rambutan, duku."

Kutipan di atas menerangkan bahwa ketika mereka merasa lapar mereka hanya makan buahbuahan saja. Meskipun Si Supak dan Si Gantang hanya makan buah-buahan saja, Si Gantang dan Si Supak Terus Berjuang untuk memenuhi Kebutuhan Hidup.

Perjuangan hidup dapat dilihat pada kutipan berikut:

Pada suatu hari, Mang Raja Haji pergi untuk mencari ikan. Pagi-pagi sekali ia berangkat. Ketika itu ketujuh putrinya masih tidur nyenyak. Udara pagi begitu dingin membuat seluruh tulang menjadi beku dan kaku, namun tidak dengan Mang Raja Haji. Ia seakan sudah terbiasa dengan udara dingin bahkan lebih dari itu.

Kutipan di atas menerangkan kalau hari masih sangat pagi sekali, udara terasa sangat dingin seakan membekukan seluruh badan. Namun tidak bagi Mang Raja Haji, ia seakan sudah terbiasa dengan keadaan seperti itu. Walaupun udara terasa dingin Mang Raja Haji tetap berangkat untuk mencari ikan. Saat ia berangkat ketujuh putrinya masih tidur nyenyak. Dengan mencari ikan Mang Raja Haji berharap dapat menhidupi dirinya dan juga ketujuh putrinya tersebut. Mang Raja Haji terus berjuang meskipun apa yang harus ia lewati tidaklah mudah, bagi Mang Raja Haji meskipun udara tersebut dapat membekukan seluruh tulangnya, Mang Raja Haji terus berusaha untuk mencari ikan yang bahkan belum tentu ikan itu ia dapatkan.

\section{Peduli Sesama}

Peduli sesama merupakan perilaku tenggang rasa yang mau saling berbagi dengan orang lain.

Dengan saling berbagi kepada orang lain, merupakan salah satu sikap peduli kepada sesama.

Peduli kepada sesama dapat dilihat pada kutipan berikut:

Ibunya tertawa geli melihat perilaku Si Gantang dan Si Supak, karena dedaunan yang mereka bawa sebenarnya tidak dapat digunakan untuk mengobati Ayahnya yang sedang sakit. "Seharusnya kalian menanyakan terlebih dahulu daun apa yang dapat digunakan mengobati penyakit tekanan darah tinggi, jangan asal petik saja." kata Ibunya. 
Kutipan di atas menerangkan walaupun Si Gantang dan Si Supak tidak mengetahui daun apa yang dapat digunakan untuk mengobati Ayahnya, tetapi karena rasa pedulinya terhadap orang tua, mereka tetap mencari dedaunan tersebut. Meskipun ramuan obat yang diberikan kepada ayahnya itu dedaunan yang salah, Si Gantang dan Si Supak tidak menyerah untuk mencoba membuat ramuan obat dari dedaunan yang mereka dapatkan dihutan. Namun pada akhirnya usaha tersebut belum membuahkan hasil seperti yang mereka harapkan, yaitu untuk menyembuhkan ayahnya yang sedang sakit.

\section{Nilai Pendidikan Moral dalam Cerita Rakyat Bakumpai \\ Pantang Menyerah}

Pantang menyerah merupakan sikap yang suka bekerja keras, selalu bersemangat dan selalu berjuang secara maksimal untuk mencapai apa yang diinginkan dan apa yang dicita-citakannya bisa terwujud.

Wujud pantang menyerah dapat dilihat pada kutipan berikut:

Selain itu, walaupun dalam keadaan sakit-sakitan, Ayahnya tetap dapat memberikan bimbingan dan didikan kepada Si Gantang dan Si Supak. Ada yang menyebut ayahnya mengidap penyakit rematik dan tekanan darah tinggi. Segala macam obat telah diminum, seperti daun seledri, daun luntas dan buah mentimun, tetapi usaha itu belum juga berhasil.

Kutipan di atas menerangkan bahwa walaupun dalam keadaan sakit-sakitan, Ayah tetap memberikan bimbingan dan didikan kepada Si Gantang dan Si Supak. Si Gantang dan Si Supak tidak menyerah untuk mencari dedaunan dihutan guna, agar dapat dibuat ramuan obat yang dapat menyembuhkan ayah mereka, Si Gantang dan Si Supak terus mencoba, namun usaha mereka tidak memberikan hasil seperti yang mereka harapkan, yaitu untuk kesembuhan ayahnya yang sedang sakit.

\section{Semangat}

Semangat adalah selalu berusaha dengan penuh motivasi tanpa kenal lelah untuk mendapatkan hasil yang diharapkan. Menghilangkan rasa malas dalam diri dan menumbuhkan motivasi, serta bekerja lebih keras dan penuh semangat untuk mancapai hasil yang diinginkan.

Semangat dapat dilihat pada kutipan berikut:

"Pagi-pagi benar, matahari belum terbit, dengan membawa alat-alat perburuan, makanan dan minuman yang sudah disiapkan sebelumnya, mereka pergi untuk menunggu binatang yang kehausan untuk minum." 
Pada kutipan di atas menerangkan bahwa ketika hari masih pagi, dengan membawa alat berburu, serta bekal yang sudah disiapkan, mereka (Si Gantang dan Si Supak) segera pergi ke hutan di tepi sungai untuk menunggu binatang yang ingin minum di sungai (mengintai binatang buruannya). Dengan semangat yang begitu besar Si Gantang dan Si Supak berharap mereka pulang dapat membawa binatang buruan mereka untuk diberikan kepada ibu mereka.

\section{Tanggung Jawab}

Tanggung jawab merupakan suatu kewajiban menanggung sesuatu. Bentuk tanggung jawab adalah pertanggungjawaban atas kesalahan atau perbuatan yang disengaja atau tidak disengaja. Dalam hal ini, siap menerima hukuman sebagai bentuk pertanggungjawaban atas kesalahan yang dilakukan.

Sikap bertanggungjawab dapat dilihat pada kutipan berikut:

Beberapa waktu yang lalu salah seorang temannya yang sedang bermain di tepi pantai, hampir saja dimangsa buaya yang tiba-tiba muncul, untung saja ada rakit, sehingga ia berhasil menyelamatkan diri dari serangan buaya. Walau banyak bahaya yang mengancam anak-anaknya, Ibu Si Gantang dan Si Supak tidak dapat berbuat apa-apa, karena anak-anaknya tidak peduli lagi dengan nasehatnya. Segala bahaya, baik itu yang berasal dari binatang di sungai maupun di darat tidak dihiraukan, karena mereka belum banyak berakal. Walaupun demikian, tetap saja ibu si Gantang dan si Supak merasa cemas terhadap mereka, karena biar bagaimanapun Si Gantang dan Si Supak adalah anaknya dan tanggungjawabnya.

Pada kutipan di atas menerangkan tentang perasaan Ibu Si Gantang dan Si Supak. Ia merasa cemas akan keselamatan anak-anaknya, karena anak-anaknya tidak mendengarkan apabila diberi nasihat bahwa di luar sana banyak bahaya yang mengintai. Hal ini disebabkan karena anak-anaknya yang belum matang berfikirnya. Sifat ibu Si Gantang dan Si Supak yang mencemaskan anakanaknya tersebut menggambarkan bahwa ibu Si Gantang dan Si Supak Memiliki Rasa tanggungjawab yang tinggi kepada Si Gantang dan Si Supak. Karena Si Gantang dan Si Supak adalah anak-anaknya yang ia besarkan dengan sepenuh hati. 


\section{SIMPULAN}

Berdasarkan analisis terhadap Cerita Rakyat Bakumpai, dapat disimpulkan bahwa cerita ini banyak mengandung nilai pendidikan diantaranya: 1) Nilai pendidikan sosial, dan 2) Nilai pendidikan moral. Yang mana berhubungan dengan kehidupan sehari-hari, yaitu sebagai berikut.

1. Nilai Pendidikan Sosial dalam Cerita Rakyat Bakumpai ialah: (a) tolong-menolong dalam cerita tersebut sama-sama memiliki perilaku saling tolong-menolong. (b) Keteguhan hati dengan keyakinan dan keteguhan hati terus berharap, agar ayah mereka dapat sembuh kembali. (c) Setia kawanan dalam keadaan apapun, mereka selalu membaginya satu sama lain. (d) Perjuangan hidup dari masing-masing tokoh disampaikan secara tersurat. (e) Peduli sesama dalam kedua cerita tersebut yaitu sama-sama memiliki sifat peduli sesama.

2. Nilai Pendidikan Moral dalam Cerita Rakyat Bakumpai adalah (a) pantang menyerahdalam cerita itu yaitu sama-sama memiliki sifat pantang menyerah yang tertanam dalam diri mereka masing-masing. (b) Semangat seperti yang tergambar dalam kedua cerita tersebut yaitu mereka memiliki semangat yang tinggi (c) Tanggungjawab yang tinggi ditunjukkan oleh sosok ibu dan ayah dalam kedua cerita rakyat Bakumpai.

\section{SARAN}

1. Peneliti menyarankan perlu diadakan penelitian lanjutanyangmengambil sisi lain dari cerita rakyat Bakumpai tersebut, agar unsur-unsur yang terkandung di dalamnya dapat lebih digali, sehingga dapat diambil manfaatnya.

2. Peneliti menyarankan perlu adanya pengenalan dan pengembangan terhadap cerita rakyat Bakumpai, agar masyarakat lebih berminat membacanya.

\section{DAFTAR RUJUKAN}

Akbar, S., dkk. 2013. Kajian Sosiologi Sastra dan Nilai Pendidikan dalam Novel "TuanGuru” Karya Salman Faris. Magister Pendidikan Bahasa Indonesia Program PascasarjanaUNS.

Setia, E. 1990. Fungsi dan Kedudukan Sastra Lisan Melayu Serdang. Jakarta: Pusat Pembinaan dan Pengembangan Bahasa.

Zaidan, A. R., dkk. 2007. Kamus Istilah Sastra. Jakarta: Balai Pustaka. 